\title{
REMOTE SENSING AND GIS BASED WATERSHED MANAGEMENT IN MALATTAR NARI-AR RIVER - A CASE STUDY
}

\author{
Dr. N. Nagarajan"; Dr. K. Karthikeyan²; Dr. S. Sivaprakasam³ \\ R.S. Soundharya ${ }^{4}$ \\ ${ }^{I}$ Associate Professor, Department of Civil Engineering, Annamalai University, Tamilnadu, India. \\ ${ }^{2}$ Associate Professor, Department of Civil Engineering, Annamalai University, Tamilnadu, India \\ ${ }^{3}$ Associate Professor, Department of Civil Engineering, Annamalai University, Tamilnadu, India. \\ ${ }^{4}$ Post Graduate Student, Department of Civil Engineering, Annamalai University, Tamilnadu, India. \\ ${ }^{1}$ nnrajan.au@gmail.com; ${ }^{2}$ srikrish.k.karthikeyan@gmail.com; ${ }^{3}$ sivacdm67@gmail.com; \\ soundharyakrishnan1610@gmail.com
}

\section{ABSTRACT}

DOI: 10.26821/IJSHRE.9.4.2021.9417

Watershed management is the management of all the natural resources of drainage basin to protect, maintain or improve its water yields. It has been defined as the analysis, protection, repair and utilization of drainage basins for optimum control and conservation of water with due regard to other resources. The concept of watershed management is the recognition of the interrelationships among land use, soil and water and the linkages between uplands and downstream areas. The integration of various aspects of hydrology, ecology, soils, physical climatology, and other sciences provide the scientific base of watershed management. Watershed is a logical unit for the efficient management of rainwater in the dry regions. Along with water, other natural resources, such as soil, vegetation and biota, can also be managed efficiently by adopting an integrated watershed-management approach. In this paper, drainage morphometry analysis deciphered the characteristics of the Malattar Nari Ar watershed and SCS-CN rainfall runoff method used to understand the surface water potential in terms of surface runoff. These two analyses help to suggest suitable structural and non structural measures to improve the watershed for better management.

Keywords: $\quad$ Rainfall runoff, GIS, NRCS - CN runoff curve number method, slope Land use, hydrological soil group

\section{INTRODUCTION}

The term watershed consists of two words: water and shed. Water occurs in nature mostly in solid, liquid and vapour forms. In watershed, water is considered mainly in liquid form. The word "shed" refers to the roof of a shed which collects rainwater and drains out. Shed thus can be defined as an area well marked by a boundary which receives rainwater and drains out towards a common drainage point or outlet. Watershed is a topographically delineated area drained by a stream system i.e. the total land area above some point on a stream or river that drains down slope to the lowest point. A watershed is a hydrological unit also used as physicalbiological or socio-economic political unit for planning and management of natural resources for increasing productivity, generating employment, overall socio-economic development and consequently the well being of 
Volume 9 Issue 4 April 2021

the people. Watershed management involves the judicious use of natural resources with active participation of organizations in harmony with the eco-system. Depending upon the size of the watersheds, these are broadly divided into sub, mini, micro- and macro-watersheds, the Malattar Nari Ar watershed was selected for this study.

Remote sensing technique is a unique tool which provides information on spatial distribution of various landscapes, vegetative density and types, land forms, drainage and erodibility status. The space borne data combined with field survey data can provide precise hybrid database for optimal watershed development plan. Remote sensing data combined with Geographic Information System (GIS) is a holistic approach to map and generate spatial input layers for predicting response behaviour and yield of watershed. It also helps in finding optimum land, soil, crop suitability and judicious crop planning. GIS is used to manage and model various spatial data sets as a tool for characterization prioritization, developmental planning and monitoring.

The remote sensing data combined with the available collateral data are useful to evaluate the groundwater potential in Malattar-Nari Ar watershed. Groundwater potential is expected to be available in the alluvium, sedimentary zone and buried pediment deep, lineament zone area. Using Remote Sensing data, various thematic layers were generated with limited field check. The thematic maps were analyzed under GIS environ to determine groundwater potential zonation map. The LISS III data of IRS P6 2017 was used to prepare satellite image map of Malattar-Nari Ar watershed of Pennaiyar river basin. Further IRS LISS III of P6, 2008 data was used to delineate geomorphic and lineament features. Landuse, soil, lithology and digital elevation model derived from remote sensing and GIS technologies were utilized for NRCS-CN modeling for estimating rainfall runoff and surface water potential in the Mallatar-Nari Ar watershed. The objectives of the present study are as follows they are:

- To estimate the daily runoff of the watershed using NRCS-CN method.

- To study the morphometric analysis of the watershed with respect to the drainage pattern.

\section{STUDY AREA}

The study area Malattar-NariAr -NariAr -NariAr watershed is located in the north eastern part of the Pennaiyar basin. Malattar-NariAr -NariAr watershed is bounded by T.Edayur watershed in the south west, Malattar watershed in the south, Nellikuppam watershed in the south east, Villupuram watershed in the north west, Pallichcheri watershed in the north and north east and Bay of Bengal in the east (Figure 1). The study area Malattar-NariAr watershed is located in between north latitudes $11^{\circ} 47^{\prime} 30^{\prime \prime} \mathrm{N}$ to $11^{\circ} 58^{\prime} 15^{\prime \prime} \mathrm{N}$ and east longitudes $79 \circ 20^{\prime} 45^{\prime \prime} \mathrm{E}$ to $79 \circ 48^{\prime} 45^{\prime}$ '. It is covering mostly (80\%) in Villupuram district, and about $20 \%$ in Cuddalore district of Tamil Nadu. The watershed occupies an aerial extent of 240.46 sq.km covering most of the areas in Villupuram, Cuddalore andThirukovilur taluks.

Malattarriver is a tributary of Pennaiyar which routed from Dalavanur, Arasamangalam in Koliyanur block of Villupuram district. After running $16.32 \mathrm{Km}$ towards south east, the river turned at Kangambattu to north and north eastern direction uptoPakkam at a distance of $11.12 \mathrm{Km}$. After that the river take a direction towards south east and confluence with Bay of Bengal near Pannittittu after running $16.22 \mathrm{Km}$. The total length of the Malattar river is $43.70 \mathrm{Km}$. Another river called NariAr is the distributory of Malattar river running 
through Purasanur, VenkatadriAgaram, Siruvandadu and joins with Malattar near Kangambattu. The total length of NariAr river is $13.55 \mathrm{Km}$. Agriculture is the main occupation of the people with $47 \%$ of the population engaged in it. Paddy is the major crop cultivated in this district. Groundnuts, Sugarcane, Cereals, Millets and Pulses are the other major crops cultivated. Malattar and Nari rivers along with tanks and wells are the main sources of irrigation in this watershed.

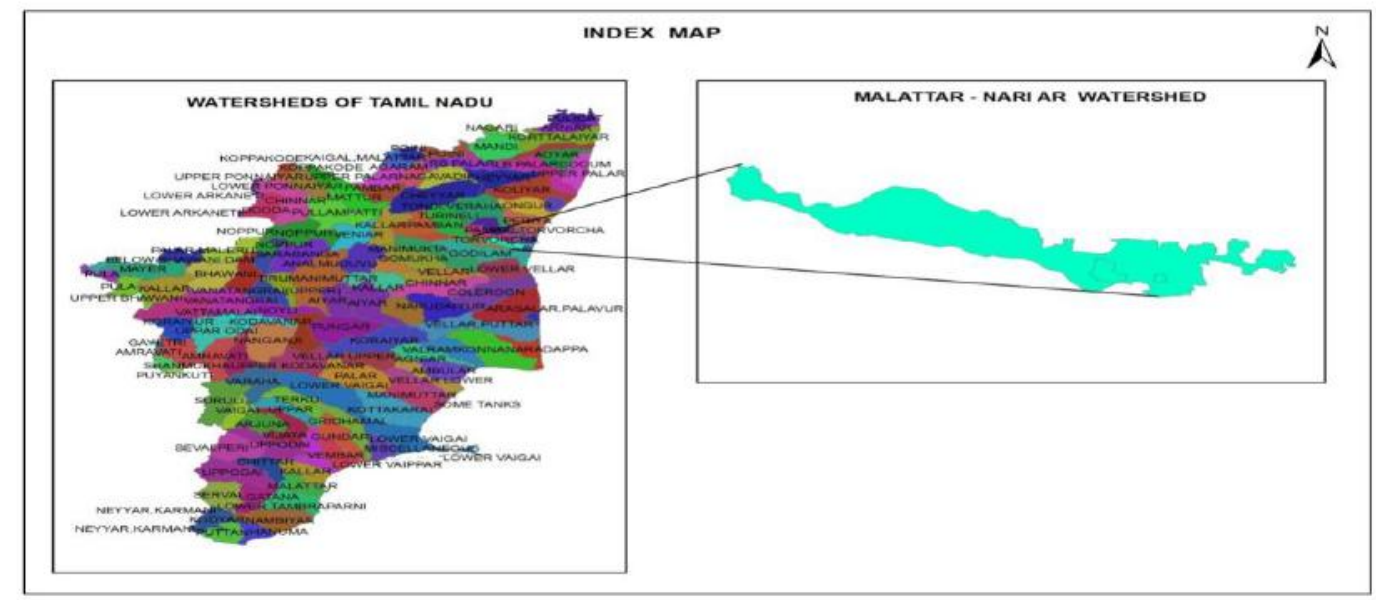

Figure 1 Location map

\section{METHODOLOGY}

The methodology used for this research study is presented in Figure 2 which shows the workflow for the development of runoff model. The watershed boundary has been delineated using the drainage patterns in the Survey of India topo sheets $58 \mathrm{M} / 5,58 \mathrm{M} / 9$ and $58 \mathrm{M} / 13$ on 1:50000 scale and the elevation ridges from the Digital Elevation Model (DEM) of SRTM, $30 \mathrm{~m}$ resolution. Drainage has also been derived from the Survey of India topo sheets.

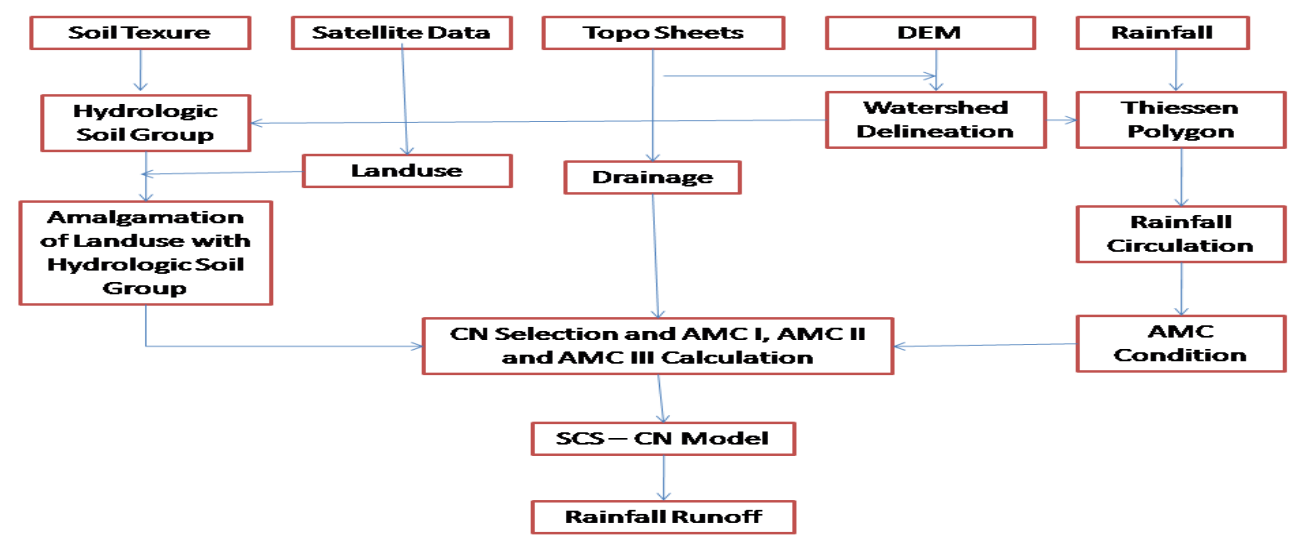

Figure 2 Methodology Flow chart

Third level classification was made to prepare Land Use map (Figure 3) from IRS P6 LISS III 2017. Soil texture of the study area was obtained from Soil Atlas of Tamil Nadu Agricultural University, Coimbatore. Slope was derived from the SRTM DEM. Rainfall data for the period 1988 to 2018 have been obtained from State Ground and Surface Water Resource Data Centre of Water Resource Department. The soil textures converted into hydrological soil groups like A, C and D according to their infiltration capacity. The land use 
categories were overlaid on the hydrologic soil groups and area for each land use class of particular soil group was find out and then assigned a curve number to each unique polygon, based on standard SCS curve number. The curve number for drainage watershed of area-weighting calculated from the land use-soil group polygons within the drainage basin boundaries.

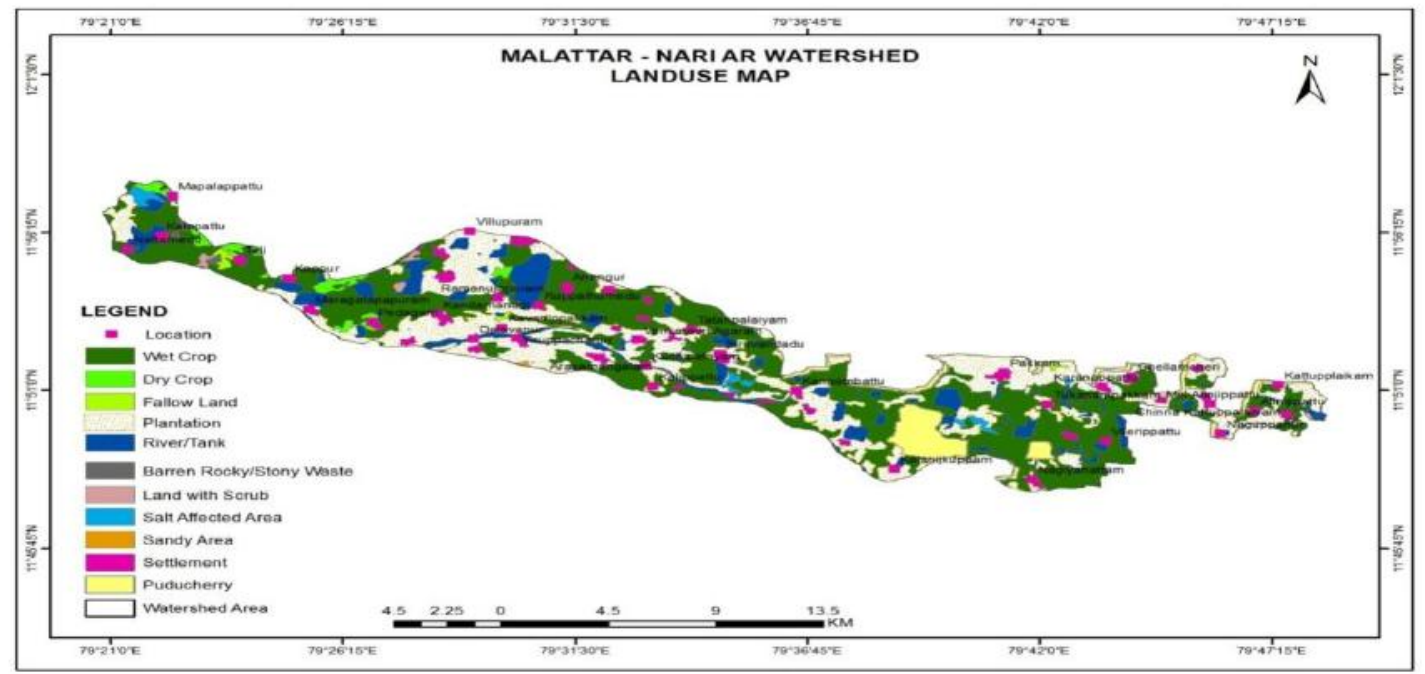

Figure 3 Land Use map

\section{Drainage Morphometric Analysis}

Identification of various surface features such as geological structures, geomorphic units and their hydraulic characteristics shall serve as direct or indirect communication of the presence of groundwater as well as surface water. The conditions of geomorphic formation are essential pre-requests in understanding water behaviors in the hard rocks. The formation of rock types and geological structures in the development of drainage networks can be better understood by exploring the nature and drainage pattern types by the morphometric analysis. The morphometric parameters are reflective of a basin hydrological response to a considerable extent and helpful in synthesizing its hydrological behavior. A quantitative morphometric characterization of a basin is considered to be the most useful method for the planning and management of the basin because it enables to understand the relationship among different aspects of the drainage patterns and also to make a comparative evaluation of different drainage basins developed in various geologic and climatic regimes.

Remote sensing and GIS techniques are the efficient tool in drainage morphometric analysis. For detailed morphometric analysis of Malattar Nari Ar watershed drainage layer has been converted into digital format through on-screen digitization from Survey of India topo sheets in 1:50000 scale using ArcGIS 10.3 GIS software and suitable attributes were given to create digital database.

The morphometric parameters were directly computed from the vector data extracted from the topo sheets. The data in the first category includes maximum order of the streams, number of streams in each order, length, area, perimeter and relief. Those of the second category includes the bifurcation ratios, elongation factor, circularity index, shape factor, drainage density, stream frequency, texture ratio, relief ratio, length of overland flow, constant channel maintenance and infiltration number. Linear, aerial and relief aspects of the basin were 
iJournals: International Journal of Software \& Hardware Research in Engineering (IJSHRE)

ISSN-2347-4890

Volume 9 Issue 4 April 2021

calculated in GIS environment and given in Table 1 followed by simple linear regression analysis to check the mutual dependency of some variables viz.,

1. Stream order Vs Stream number

2. Stream order Vs Stream length

3. Stream order Vs Mean stream length

Table 1 Morphometric parameters

\begin{tabular}{|c|c|c|c|c|}
\hline Sl. No. & Aspect & Parameter & Unit & Value \\
\hline 1 & Aerial & Area(Sq.km) & A & 240.46 \\
\hline 2 & \multirow{8}{*}{ Linear } & Perimeter(km) & $\mathrm{P}$ & 160.87 \\
\hline 3 & & Basin Length $(\mathrm{km})$ & $\mathrm{L}_{\mathrm{b}}(\mathrm{km})$ & 53.57 \\
\hline 4 & & Stream Order & (u) & $1,2,3$ \\
\hline 5 & & Stream Length of all order & $\mathrm{L}_{\mathrm{u}}$ & 302.92 \\
\hline 6 & & Total number of stream segments in all orden & $\mathrm{N}_{\mathrm{u}}$ & 231 \\
\hline 7 & & Total number of first order & $\mathrm{N} 1$ & 150 \\
\hline 8 & & Mean stream length $(\mathrm{Km})$ & $\mathrm{Lsm}=\mathrm{L}_{\mathrm{u}} / \mathrm{N}_{\mathrm{u}}$ & 1.31 \\
\hline 9 & & Bifurcation Ratio & $\mathrm{R}_{\mathrm{b}}=\mathrm{N}_{\mathrm{u}} / \mathrm{N}_{\mathrm{u}}+1$ & 5.30 \\
\hline 10 & \multirow{3}{*}{ Relief } & Basin relief & $\mathrm{B}_{\mathrm{h}}$ & 86.00 \\
\hline 11 & & Relief Ratio & $\mathrm{R}_{\mathrm{h}}$ & 1.61 \\
\hline 12 & & Ruggedness Number & $\mathrm{Rn}$ & 108.34 \\
\hline 13 & \multirow{10}{*}{ Aerial } & Drainage density $(\mathrm{km} / \mathrm{km} 2)$ & $\mathrm{D}_{\mathrm{d}}=\mathrm{L}_{\mathrm{u}} / \mathrm{A}$ & 1.26 \\
\hline 14 & & Stream frequency & $\mathrm{F}_{\mathrm{s}}=\mathrm{N}_{\mathrm{u}} / \mathrm{A}$ & 0.96 \\
\hline 15 & & Drainage texture & $\mathrm{R}_{\mathrm{t}}=\mathrm{N}_{\mathrm{u}} / \mathrm{P}$ & 1.44 \\
\hline 16 & & Circularity ratio & $\mathrm{Rc}=4 \Pi \mathrm{A} / \mathrm{P}^{2}$ & 0.12 \\
\hline 17 & & Form factor ratio & $\mathrm{Rf}=\mathrm{A} / \mathrm{L}_{\mathrm{b}}^{2}$ & 0.08 \\
\hline 18 & & Constant channel maintenance & $\mathrm{C}=1 / \mathrm{D}_{\mathrm{d}}$ & 0.79 \\
\hline 19 & & Elongation ratio & $\mathrm{R}_{\mathrm{e}}=2\left((\sqrt{ }(\mathrm{A} / \boldsymbol{\Pi})) / \mathrm{L}_{\mathrm{b}}\right.$ & 0.33 \\
\hline 20 & & Texture ratio & $\mathrm{T}=\mathrm{N} 1 / \mathrm{P}$ & 0.93 \\
\hline 21 & & Infiltration Number & If & 1.21 \\
\hline 22 & & Length of overland flow & $\mathrm{Lg}$ & 0.63 \\
\hline
\end{tabular}




\section{SCS-CN MODEL}

The SCS-CN (1985) model method has been introduced in 1954 by the USDA SCS defined in the Soil Conservation Service (SCS) by National Engineering Hand Book (NEH-4), Section of Hydrology. The approach of Soil conversations Service-Curve Number is based on the water balance calculation and two fundamental hypotheses. The first hypothesis states that the ratio of the real quantity of direct runoff to the maximum possible runoff is equal to the ratio of the amount of real infiltration to the quantity of the potential maximum retention. The second hypothesis states that the amount of early abstraction is some fraction of the probable maximum retention. The approach of Soil Conservation Service Curve Number is frequently used in empirical methods to calculate the direct runoff from a watershed (USDA 1972) in the study area.. The infiltration losses are combined with surface storage by the relation of

$$
\mathrm{Q}=(\mathrm{P}-\mathrm{Ia})^{2} /(\mathrm{P}-\mathrm{Ia})+\mathrm{S}
$$

where, $\mathrm{Q}$ is the gathered runoff in $\mathrm{mm}, \mathrm{P}$ is the rainfall depth in $\mathrm{mm}$, Ia is the initial abstraction in $\mathrm{mm}$ and surface storage, interception, and infiltration prior to runoff in the watershed and empirical relation was developed for the term Ia and it is given by, The empirical relationship is,

$$
\mathrm{Ia}=0.3 \mathrm{~S}
$$

For Indian condition the form $\mathrm{S}$ in the potential maximum retention andit is given by,

$$
\mathrm{S}=(25400 / \mathrm{CN})-254
$$

Where, $\mathrm{CN}$ is known as the curve number which can be taken from SCS handbook of Hydrology (NEH-4), section-4 (USDA 1972). Now the equation can be rewritten as,

$$
\mathrm{Q}=(\mathrm{P}-0.3 \mathrm{~S}) 2 / \mathrm{P}+0.7 \mathrm{~S}
$$

Significant the value of $\mathrm{CN}$, the runoff from the watershed was calculated from

Eqs. 3 and 4.

The SCS curve number is a purpose of the ability of soils to allow infiltration of water with respect to land use and antecedent soil moisture condition (AMC) (Amutha and Porchelvan 2009). Based on U.S soil conservation service (SCS) soils are distributed into four hydrologic soil groups such as group A, B, C and D with respect to rate of runoff probable and final infiltration.

\section{Antecedent Moisture Condition}

Antecedent Moisture Condition (AMC) is considered when little prior rainfall and high when there was considerable preceding rainfall to the rainfall model event. For the purpose of modeling, AMC II in watershed is essentially taken as an average moisture condition. Runoff curve numbers from land use and soil type taken for the average condition (AMC II) and dry conditions (AMC I) or wet condition (AMC III), equivalent curve numbers $(\mathrm{CN})$ were computed by using the following Eqs. 5 and 6 . The curve number values recognized in the case of AMC-II (USDA 1985) in Table 2.

The following equations were used in the cases of AMC-I and AMC-III (Chow et al. 2002)

$$
\mathrm{CN}(\mathrm{I})=\mathrm{CN}(\mathrm{II}) / 2.281-0.0128 \mathrm{CN}(\mathrm{II})
$$




$$
\mathrm{CN}(\mathrm{III})=\mathrm{CN}(\mathrm{II}) / 0.427+0.00573 \mathrm{CN} \text { (II) }
$$

Where, (II) CNis the curve number for normal condition, (I) CNis the curve number. For dry condition, and (III) $\mathrm{CNis}$ the curve number for wet conditions.

$$
\mathrm{CNw}=\Sigma \mathrm{CNi} * \mathrm{Ai} / \mathrm{A}
$$

Where $\mathrm{CNw}$ is the weighted curve number; $\mathrm{CNi}$ is the curve number from 1 to any number $\mathrm{N}$; $\mathrm{Ai}$ is the area with curve number $\mathrm{CNi}$; and A the total area of the watershed in Table 3.

Table 2 Soil Conservation Service classification (USDA 1974)

\begin{tabular}{|c|c|c|c|c|}
\hline $\begin{array}{c}\text { Hydrologic } \\
\text { Soil Group }\end{array}$ & Soil Texture & $\begin{array}{c}\text { Runoff } \\
\text { potential }\end{array}$ & $\begin{array}{c}\text { Transmitivity } \\
\text { Rate }\end{array}$ & $\begin{array}{c}\text { Infiltration } \\
\text { Rate (inches } \\
\text { per Hour) }\end{array}$ \\
\hline A & Sand & Very low & Very High & 1.25 \\
\hline A & Sandyloam & Low & High & 0.85 \\
\hline C & Sandyclayloam & Moderate & Moderate & 0.59 \\
\hline D & Sandyclay & High & Low & 0.31 \\
\hline D & Clay & High & Very low & 0.13 \\
\hline D & Clayloam & High & Low & 0.25 \\
\hline D & Siltyclayloam & High & Low & 0.21 \\
\hline
\end{tabular}

Table 3 Antecedent soil moisture classes (AMC)

\begin{tabular}{|c|c|c|c|}
\hline \multirow{2}{*}{ AMC } & \multirow{2}{*}{ Soil Condition } & \multicolumn{2}{|c|}{ Five day Antecedent rainfall in mm } \\
\cline { 3 - 4 } & & Dormant Season & Growing Season \\
\hline I & Wet & Less than 19 & Less than 31 \\
\hline II & Average & 19 to 32 & 31 to 54 \\
\hline III & Heavy rainfall & More than 32 & More than 54 \\
\hline
\end{tabular}


To estimate the surface runoff depth, the hydrological equations from 3 to 4 are used. These equations depend on the value of rainfall (P) and watershed storage (S) which are calculated from the adjusted curve number. Thus, before applying Eq. (3), the value of (S) should be determined for each antecedent moisture condition (AMC). There are three conditions to hydrologic condition results are summarized in the Table 4.

Table 4 Hydrological Calculations in the watershed

\begin{tabular}{|c|c|c|c|}
\hline AMC & CN & S & P>0.3S \\
\hline I & 52.38 & 230.92 & 69.28 \\
\hline II & 72.37 & 96.97 & 29.09 \\
\hline III & 85.76 & 42.18 & 12.65 \\
\hline
\end{tabular}

\section{Hydrologic Soil Group (HSG)}

Soil textures are classified into hydrologic soil groups (HSG's) to indicate the minimum rate of infiltration obtained for bare soil after prolonged wetting. The HSG's, which are A, B, C, and D, are one element used in determining runoff curve numbers. The infiltration rate is the rate at which water enters the soil at the soil surface. It is controlled by surface conditions. HSG also indicates the transmission rate-the rate at which the water moves within the soil. This rate is controlled by the soil profile. Approximate numerical ranges for transmission rates shown in the HSG definitions were first published by Musgrave (USDA 1955). The four groups are defined by SCS soil scientists as follows:

Group A soils have low runoff potential and high infiltration rates even when thoroughly wetted. They consist chiefly of deep, well to excessively drained sand or gravel and have a high rate of water transmission (greater than $0.30 \mathrm{in} / \mathrm{hr}$ ). Group B soils have moderate infiltration rates when thoroughly wetted and consist chiefly of moderately deep to deep, moderately well to well drained soils with moderately fine to moderately coarse textures. These soils have a moderate rate of water transmission $(0.15-0.30 \mathrm{in} / \mathrm{hr})$.

Group C soils have low infiltration rates when thoroughly wetted and consist chiefly of soils with a layer that impedes downward movement of water and soils with moderately fine to fine texture. These soils have a low rate of water transmission (0.05-0.15 in/hr). Group D soils have high runoff potential. They have very low infiltration rates when thoroughly wetted and consist chiefly of clay soils with a high swelling potential, soils with a permanent high water table, soils with a clay pan or clay layer at or near the surface, and shallow soils over nearly impervious material. These soils have a very low rate of water transmission (0-0.05 $\mathrm{in} / \mathrm{hr}$ ). The Soil textures in the study area are divided into hydrologic soil groups (HSG) as A, C and D carefully in the watershed shown in Figure 4 and Figure 5. Group A indicated low runoff potential, high infiltration rate, the soils of group $\mathrm{C}$ pointed to moderately fine to moderately rough textures, moderate rate of water transmission and the soils of group D pointed to slow infiltration and possible high runoff presented in Table 6. 
iJournals: International Journal of Software \& Hardware Research in Engineering (IJSHRE)

ISSN-2347-4890

Volume 9 Issue 4 April 2021

Table 6 Weighted curve number (AMC Group)

\begin{tabular}{|c|c|c|c|c|c|c|}
\hline Landuse & $\begin{array}{l}\text { Soil } \\
\text { Type }\end{array}$ & $\begin{array}{l}\text { Area in } \\
\text { sq.km }\end{array}$ & $\mathrm{CN}$ & $\begin{array}{l}\% \text { of } \\
\text { Area }\end{array}$ & $\begin{array}{c}\text { Area } \mathrm{x} \\
\mathrm{CN}\end{array}$ & $\begin{array}{l}\text { Weighted Curve } \\
\text { Number (WCN) }\end{array}$ \\
\hline \multirow{3}{*}{ Wet crop } & A & 74.34 & 72 & 30.91 & 5352.48 & \multirow{24}{*}{$\begin{array}{l}\text { AMC I }=52.38 \\
\text { AMC II }=72.37 \\
\text { AMC III }=85.76\end{array}$} \\
\hline & $\mathrm{C}$ & 13.58 & 88 & 5.65 & 1195.04 & \\
\hline & $\mathrm{D}$ & 32.05 & 91 & 13.33 & 2916.55 & \\
\hline \multirow{2}{*}{ Dry Crop } & A & 3.06 & 76 & 1.27 & 232.56 & \\
\hline & $\mathrm{D}$ & 1.04 & 90 & 0.43 & 93.60 & \\
\hline \multirow{3}{*}{ Fallow land } & A & 0.33 & 74 & 0.14 & 24.42 & \\
\hline & $\mathrm{C}$ & 0.21 & 90 & 0.09 & 18.90 & \\
\hline & $\mathrm{D}$ & 0.57 & 93 & 0.24 & 53.01 & \\
\hline \multirow{3}{*}{ Plantation } & A & 42.64 & 32 & & 1364.48 & \\
\hline & $\mathrm{C}$ & 13.17 & & 5.48 & 948.24 & \\
\hline & $\mathrm{D}$ & 10 & & 7.91 & 1501.79 & \\
\hline \multirow{2}{*}{ Land with Scrub } & A & & 74 & 0.25 & 44.40 & \\
\hline & D & 0.23 & 58 & 0.10 & 13.34 & \\
\hline \multirow{2}{*}{$\begin{array}{l}\text { Barren Rocky / } \\
\text { Stony Waste }\end{array}$} & C & 0.28 & 91 & 0.12 & 25.48 & \\
\hline & $\mathrm{D}$ & 0.32 & 94 & 0.13 & 30.08 & \\
\hline \multirow{2}{*}{ Salt Affected Area } & A & 2.13 & 86 & 0.89 & 183.18 & \\
\hline & $\mathrm{C}$ & 0.07 & 89 & 0.03 & 6.23 & \\
\hline Sandy Area & A & 0.11 & 96 & 0.05 & 10.56 & \\
\hline \multirow{3}{*}{ Settlement } & A & 4.99 & 59 & 2.08 & 294.41 & \\
\hline & $\mathrm{C}$ & 2.05 & 81 & 0.85 & 166.05 & \\
\hline & $\mathrm{D}$ & 3.04 & 87 & 1.26 & 264.48 & \\
\hline \multirow{3}{*}{ Water Body } & A & 22.35 & 100 & 9.29 & 2235.00 & \\
\hline & $\mathrm{C}$ & 1.64 & 100 & 0.68 & 164.00 & \\
\hline & $\mathrm{D}$ & 2.66 & 100 & 1.11 & 266.00 & \\
\hline
\end{tabular}




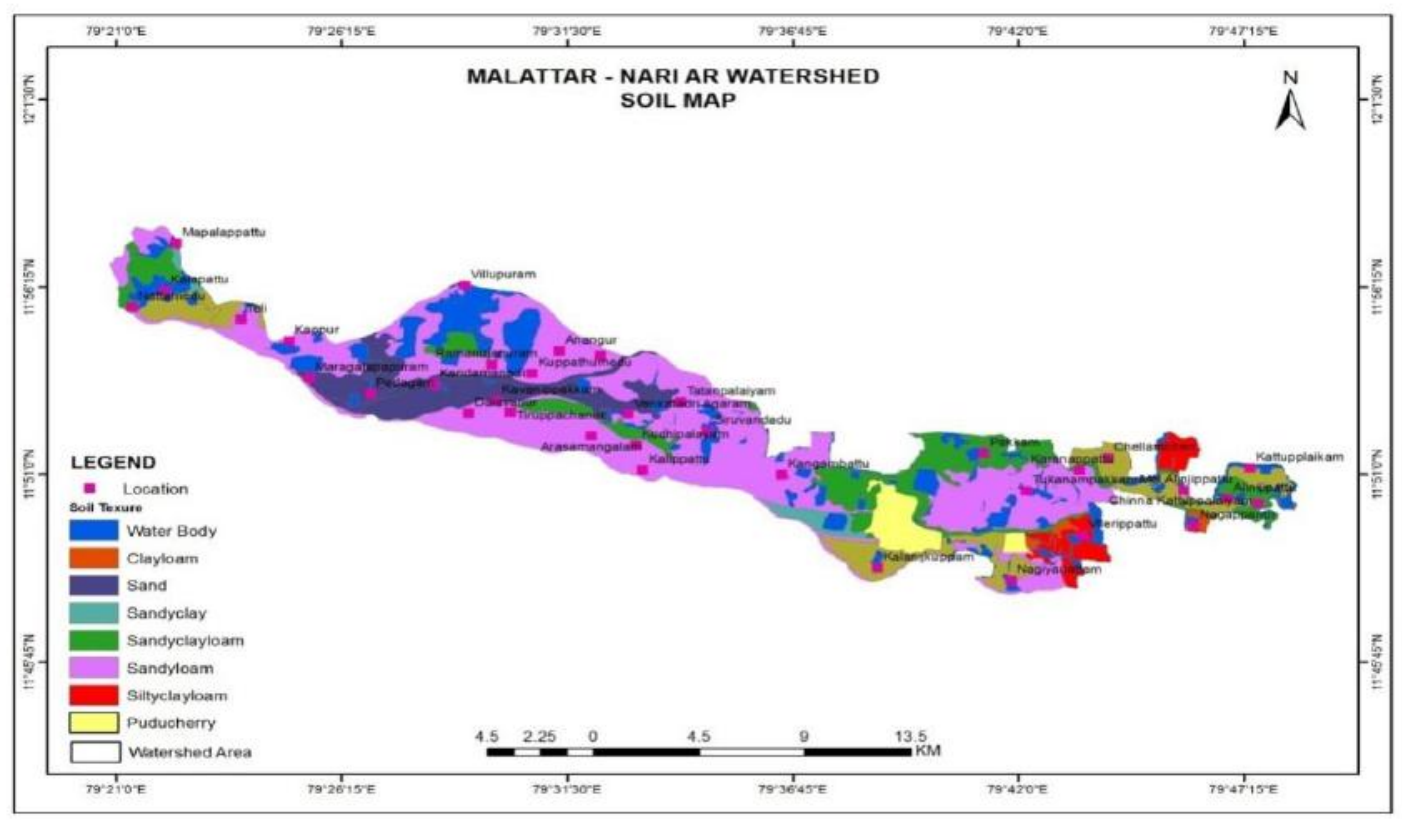

Figure 5 Soil texture

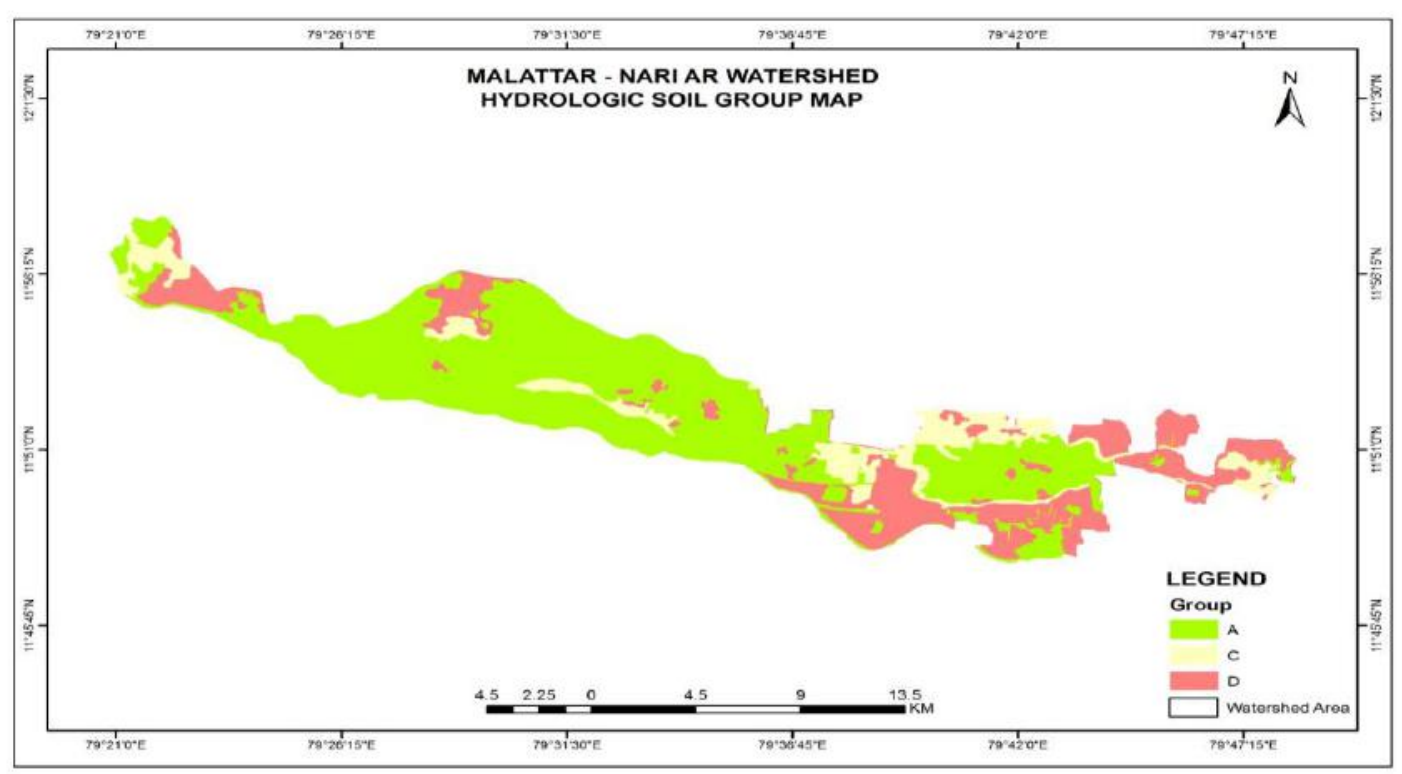

Figure 6 Hydrological Soil Group

\section{Thiessen Polygon Method}

Rainfall distribution by Thiessen polygon method accepts that the estimated values taken on the observed values of the nearby station (Nalder et al. 1998). Nearest neighbor methods are intensively examined by pattern recognition procedures. Despite their inherent simplicity, nearest neighbor algorithms are considered versatile and robust. Although more sophisticated alternative techniques have been developed since their inception, nearest neighbor methods remain very popular (Ly et al.2013). The application of rain gauge as precipitation input carries lots of uncertainties. The spatial and temporal distribution of rainfall at watershed level using GIS approaches is found to be very effective in the study area (Figure 7). 


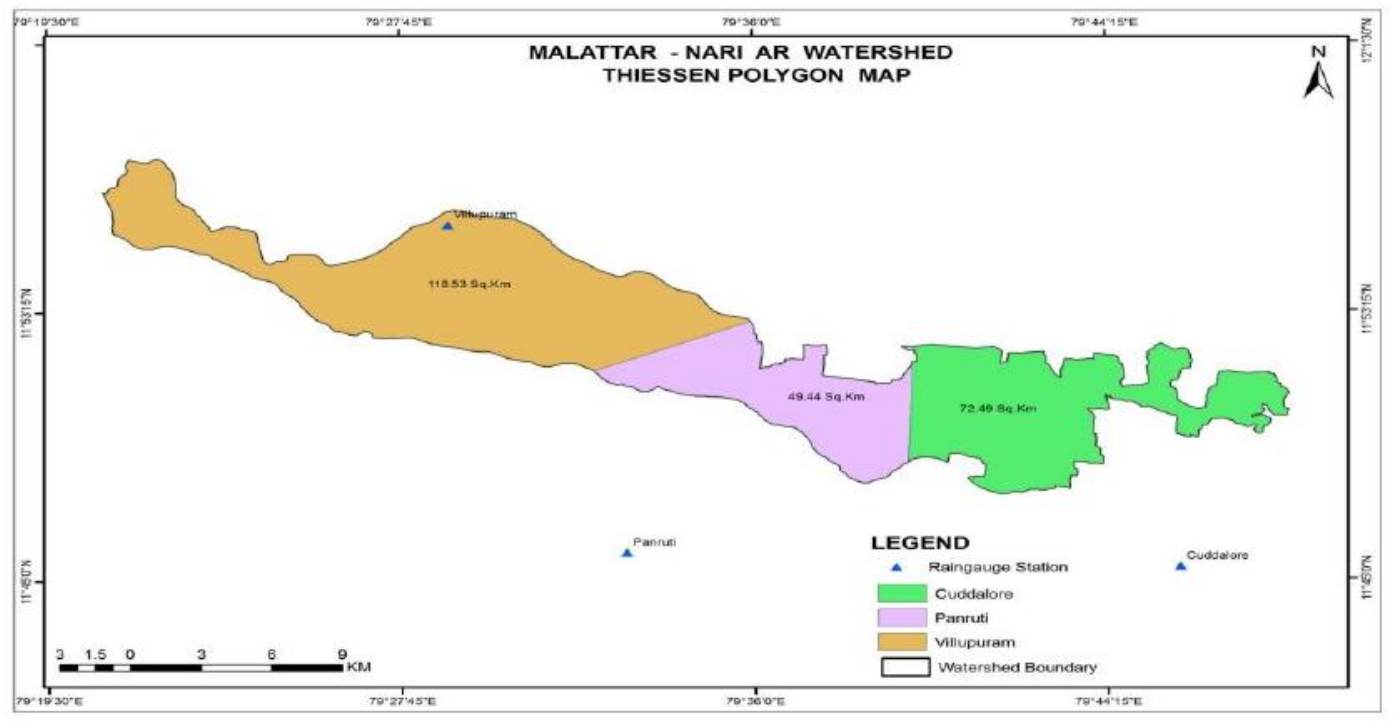

Figure 7 Thiessen Polygon

\section{Slope}

Slope was derived from SRTM DEM Vegavathi watershed falls under gentle to moderate slope class (Low to high surface runoff) representative water holding for longer time (Pawar et al. 2008) and thus improving the chance of infiltration and recharge in this study area. This is suitable site for artificial recharge structures such as check dams, vertical shafts and percolation ponds beside drainage are presented in Table $\mathbf{7}$ and also Digital Elevation model, Slope map shown in Figure 8 and Figure 9.

Table 8 Slope classes

\begin{tabular}{|c|l|c|c|}
\hline Sl. No. & \multicolumn{1}{|c|}{ \% Slope } & Area in Sq.Km & Potential implication \\
\hline 1 & Nearly Level & 84.74 & Very low surface runoff \\
\hline 2 & Gentle & 71.102 & Low surface runoff \\
\hline 3 & Moderate & 48.652 & Moderate surface runoff \\
\hline 4 & Steep & 26.724 & High surface runoff \\
\hline 5 & Very Steep & 9.242 & Very high surface runoff \\
\hline
\end{tabular}

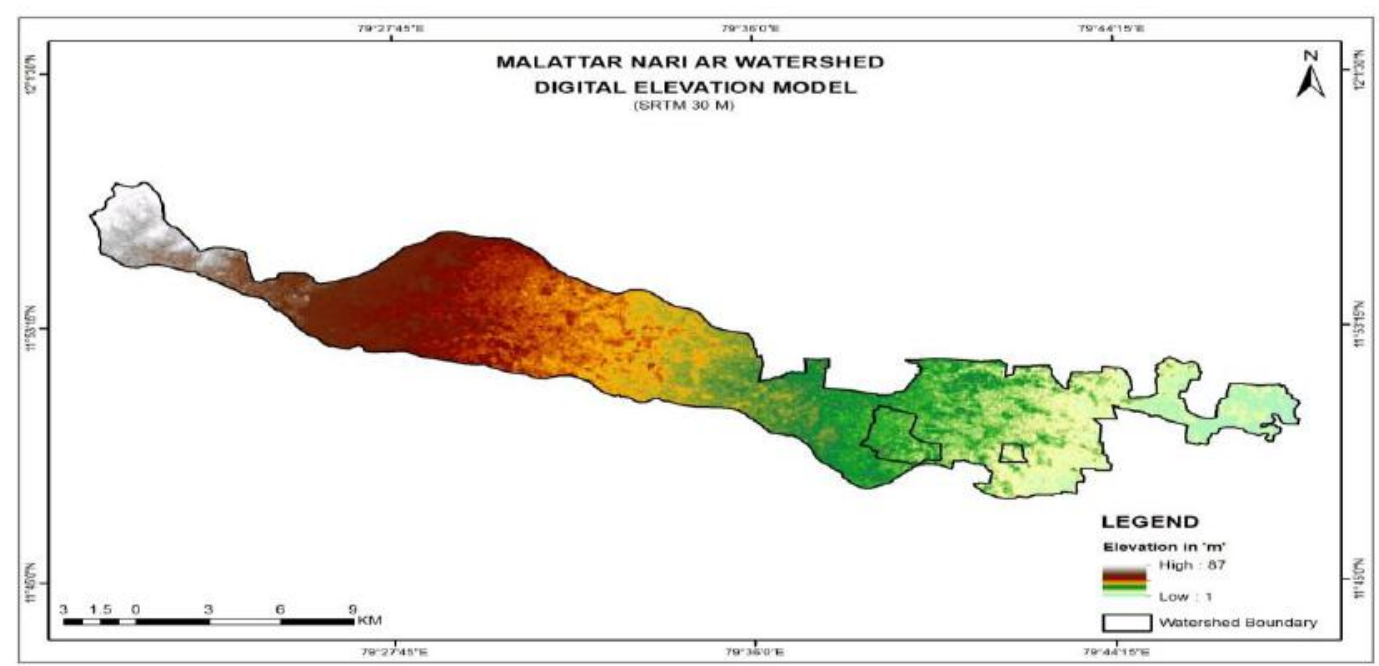

Figure 8 Digital Elevation Model 


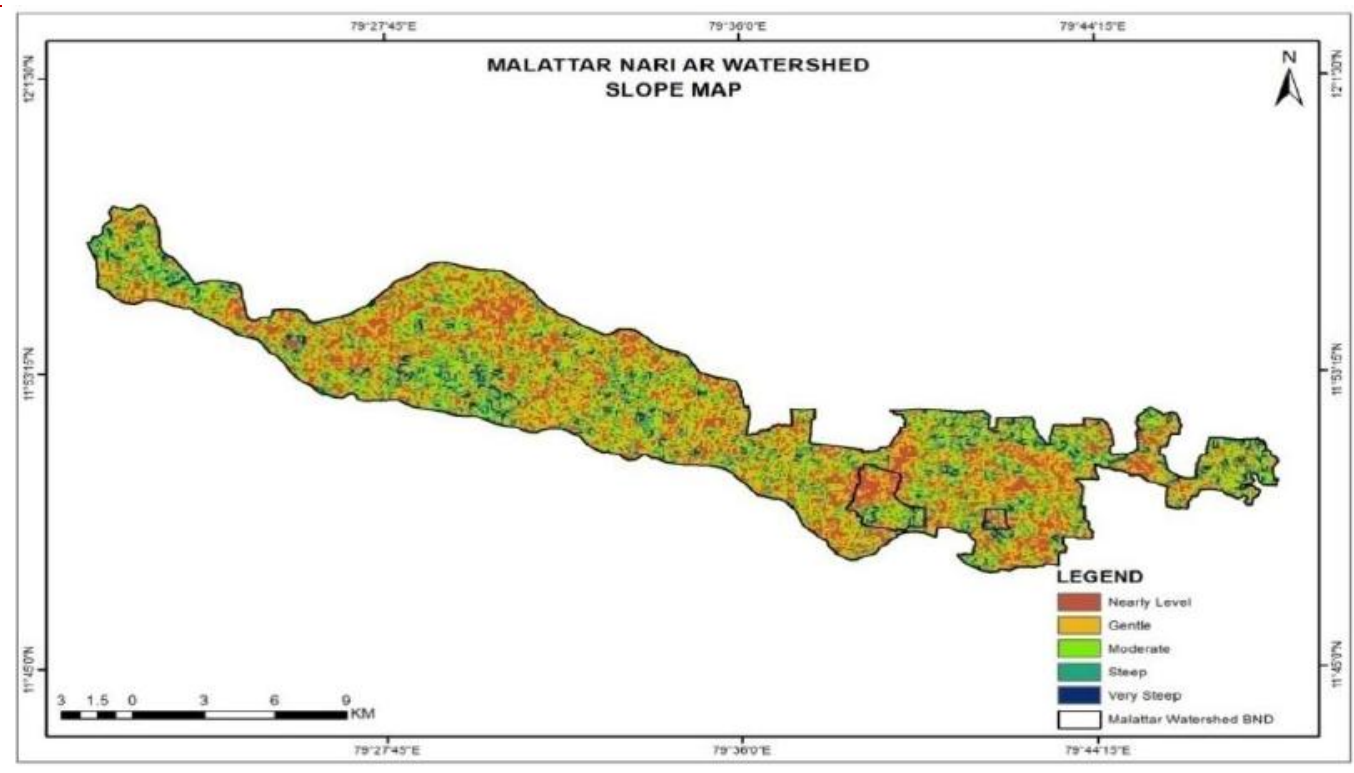

Figure 9 Slope map

In SCS method, as a result of the calculations, it was found that the average annual surface runoff depth for the last 31 years in Malattar Nari Ar watershed is equal to $526.64 \mathrm{~mm}$ and the total average volume of runoff is $175.55 \mathrm{~m}^{3}$, which represents $45 \%$ of the total average annual rainfall. The annual rainfall and runoff during 1988-2018 in the study area are shown in Table 9.

\section{RESULTS AND DISCUSSION}

The calculated normal, wet and dry conditions, curve numbers are 52.38, 72.37 and 85.76 in Figure 10. The runoff varies from 26.06 to $1609.33 \mathrm{~mm}(1988-2018)$ as shown in Figure 11. The rainfall varies between 524.56 and $1957.80 \mathrm{~mm}$ in the watershed as shown in Figure 12. The average annual runoff calculated to $526.64 \mathrm{~mm}$ and average Runoff volume for 31 years is $12.90 \mathrm{~m}^{3}$.

Table 9 Annual average runoff depth and volume

\begin{tabular}{|c|c|c|c|}
\hline Year & Rainfall in $\mathbf{~ m m}$ & Runoff in $\mathbf{~ m m}$ & Volume in $\mathbf{~}^{3}$ \\
\hline 1988 & 790.27 & 123.86 & 9.14 \\
\hline 1989 & 978.02 & 186.38 & 14.01 \\
\hline 1990 & 1393.09 & 286.76 & 25.25 \\
\hline 1991 & 972.57 & 184.71 & 14.18 \\
\hline 1992 & 839.66 & 143.47 & 11.84 \\
\hline 1993 & 1267.90 & 170.92 & 12.08 \\
\hline 1994 & 933.63 & 143.89 & 10.13 \\
\hline 1995 & 1053.30 & 100.74 & 5.97 \\
\hline 1996 & 1957.80 & 536.44 & 40.33 \\
\hline 1997 & 1520.93 & 327.71 & 27.57 \\
\hline 1998 & 1416.80 & 355.68 & 24.37 \\
\hline
\end{tabular}


iJournals: International Journal of Software \& Hardware Research in Engineering (IJSHRE)

ISSN-2347-4890

Volume 9 Issue 4 April 2021

\begin{tabular}{|c|c|c|c|}
\hline 1999 & 1088.96 & 132.22 & 8.41 \\
\hline 2000 & 1151.93 & 135.64 & 11.59 \\
\hline 2001 & 827.53 & 27.93 & 1.96 \\
\hline 2002 & 888.47 & $\begin{array}{l}51.35 \\
\end{array}$ & 3.22 \\
\hline 2003 & 1171.66 & 93.09 & 6.37 \\
\hline 2004 & 1661.27 & 279.99 & 17.71 \\
\hline 2005 & 1744.88 & 473.12 & 30.96 \\
\hline 2006 & 1356.96 & 70.49 & 4.56 \\
\hline 2007 & 1166.50 & 91.76 & 8.07 \\
\hline 2008 & 1477.43 & 351.54 & 27.00 \\
\hline 2009 & 1144.00 & 148.06 & 9.86 \\
\hline 2010 & 1525.17 & 116.66 & 7.39 \\
\hline 2011 & 1095.00 & 173.42 & 13.90 \\
\hline 2012 & 735.23 & 153.12 & 12.71 \\
\hline 2013 & 723.68 & 28.40 & 2.59 \\
\hline 2014 & 1031.43 & 49.08 & 4.51 \\
\hline 2015 & 1679.57 & & 19.66 \\
\hline 2016 & 524.56 & & 0.60 \\
\hline 2017 & 1226.19 & & 8.02 \\
\hline 2018 & 858.29 & 5 & 5.91 \\
\hline Average & 110 & 175.55 & 12.90 \\
\hline
\end{tabular}

0

The rainfall runoff relationship for Malattar Nari Ar watershed. The rainfall- runoffs are vigorously correlated with a correlation coefficient ( $\mathrm{r}$ ) value being 0.593 shown in Figure 13.

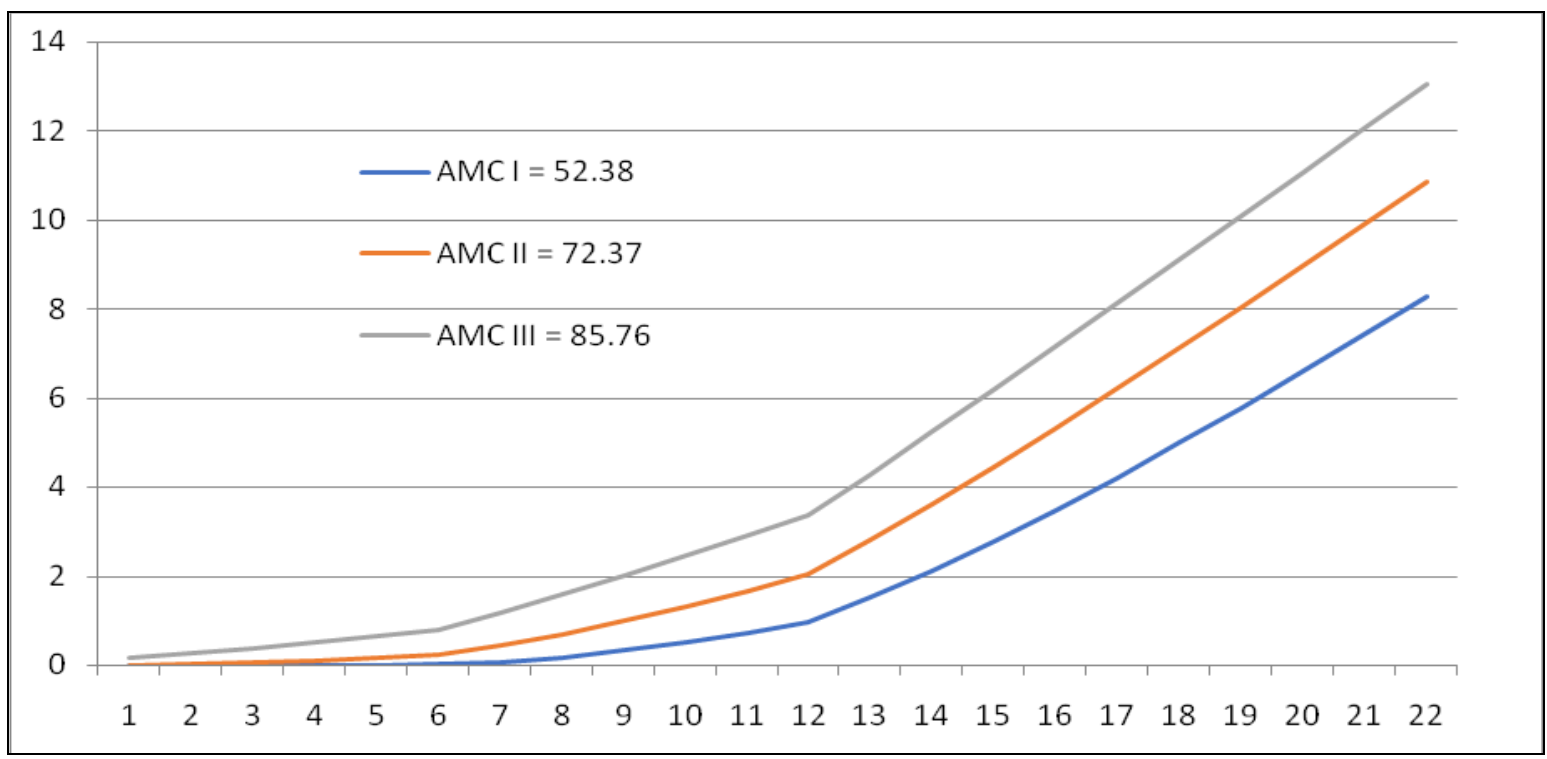

Figure 10 Solution of runoff equation 
iJournals: International Journal of Software \& Hardware Research in Engineering (IJSHRE)

ISSN-2347-4890

Volume 9 Issue 4 April 2021

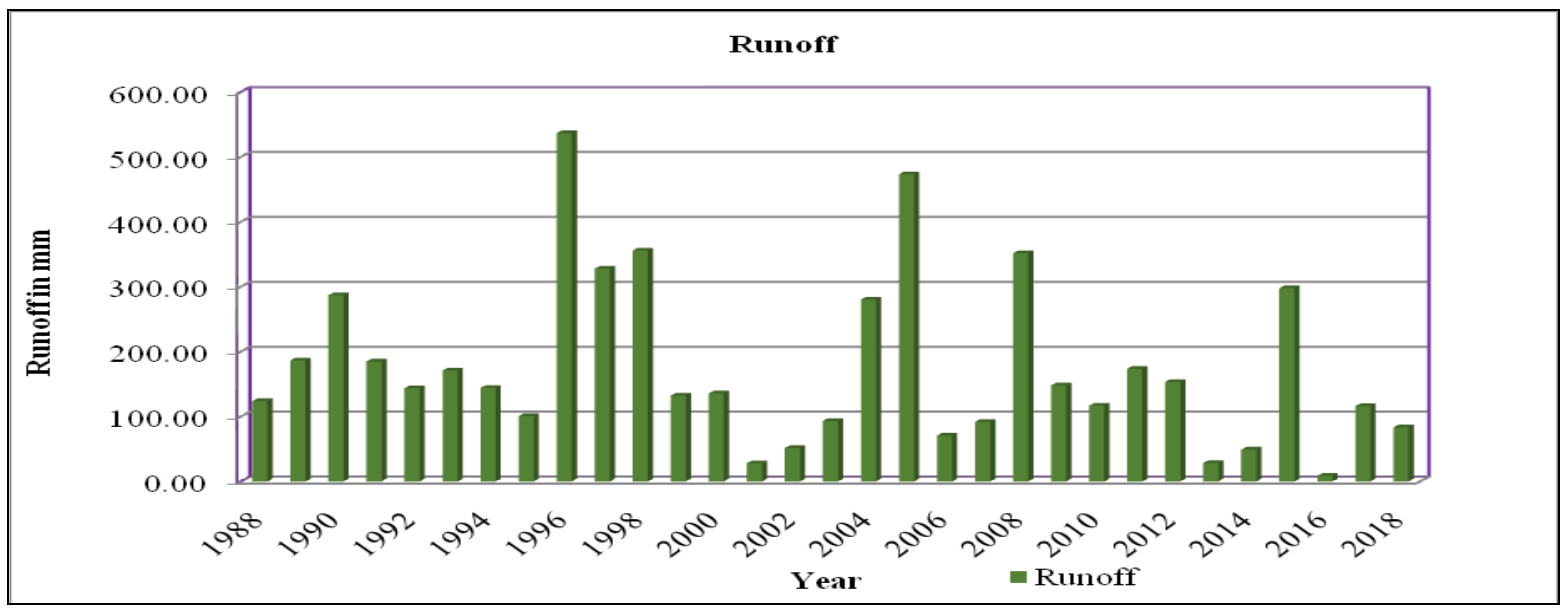

Figure 11 Runoff variation

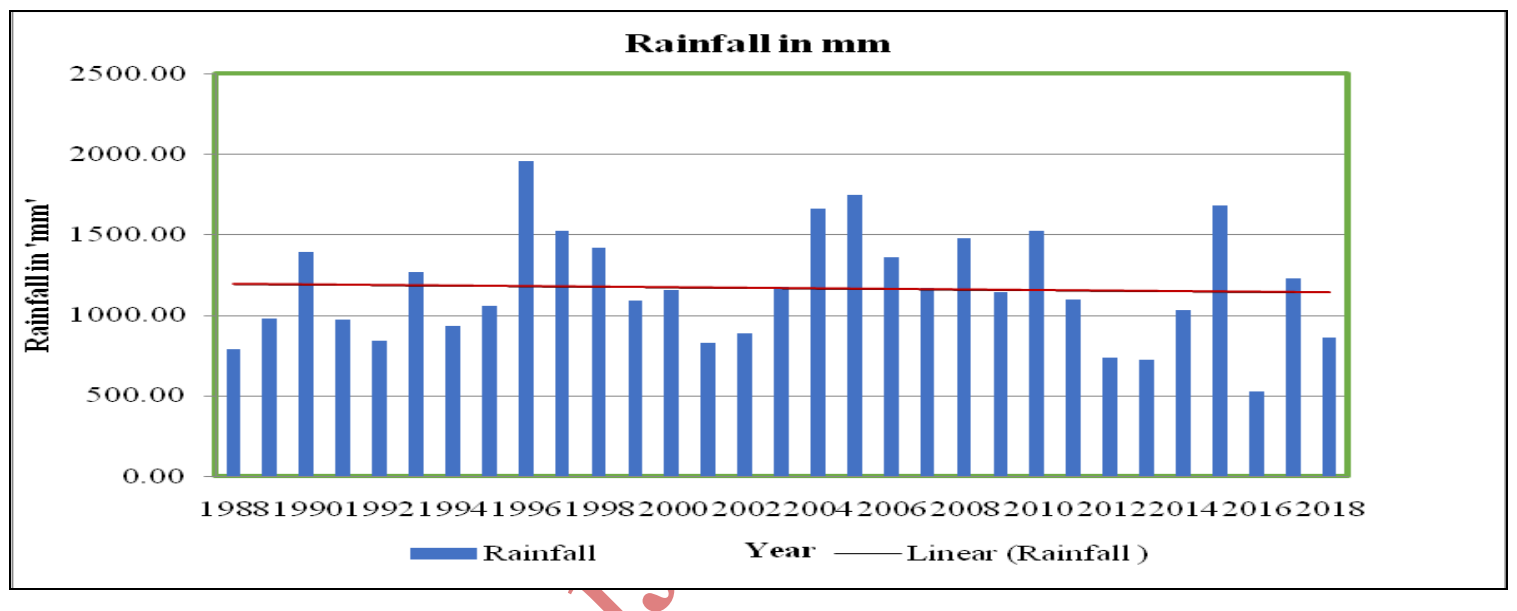

Figure 12 Rainfall variation

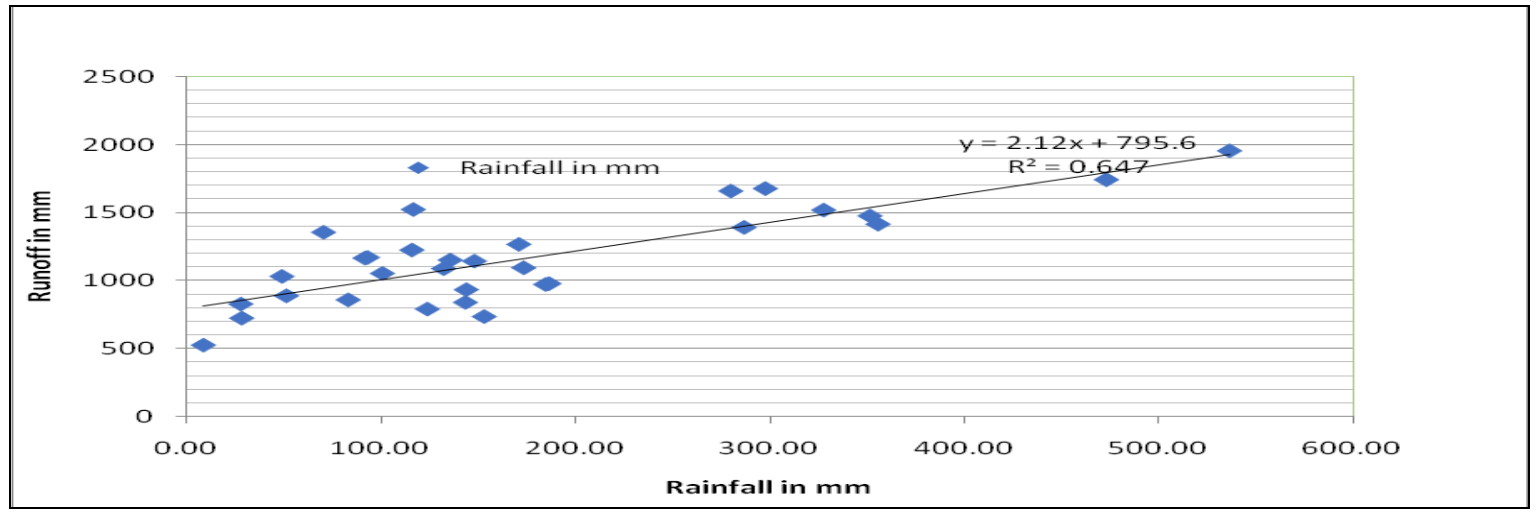

Figure 13 Scatter plot - Rainfall and calculated runoff

\section{CONCLUSION}

The SCS-CN model have been used in the present research study by utilizing DEM, land use and soil textures. The monthly rainfall runoff simulation found good relationship in the watershed. The amount of runoff 
represents $45 \%$ of the total annual rainfall. In this research study, the methodology for the tenacity of runoff using remote sensing and GIS and SCS approach could be applied in other watersheds for orchestrating of sundry conservation measures. The good soil and water conservation measures have to be planned and implemented in the watersheds such as classified as high followed by moderately high for controlling runoff and soil erosion losses. In SCN-CN method, antecedent moisture condition of the soil plays a very vital role because the $\mathrm{CN}$ number varies according to the soil texture and that is considered while estimating runoff depth. In MalattarNari watershed, CN number is calculated as 52.38 for AMC-I, 72.37 for AMC-II and 85.76 for AMCIII (Fig. 9). In conclusion, Soil Conversations Service -Curve Number approach is efficiently proven as a better method, which consumes less time and facility to handle extensive data set as well as larger environmental area to identify site selection of artificial recharge structures with the help of Remote Sensing and GIS technologies.

\section{References}

1) Chen.S.J and Singh.V.P, "Improved SCS model for computing runoff volume" Hydrology journal, Vol.16, No.1 \& 2, January-June (1993).

2) Gajbhiye.S and Mishra.S.K. Application of NRCS-SCS Curve Number Model in Runoff Estimation using RS \& GIS, IEEE (2012).

3) AnubhaTopno, Singh A.K, and Vaishya R.C "SCS/CN Runoff Estimation for Vindhyachal Region using Remote Sensing and GIS” International Journal of Advanced Remote Sensing and GIS,Vol.4, Issue 1, Pp. 1214 - 1223, ISSN 2320-0243 (2015).

4) Nagarajan.N, and Poongothai.S "Spatial Mapping of Runoff from a Watershed using SCS CN Method with Remote Sensing and GIS" Journal of Hydrologic Engineering,Vol-17,ISSN:1268-1277 (2012).

5) Poongothai.S and Thayumanavan.S, "Estimation of Runoff from a watershed using GIS based SCS method" Proceedings of National Seminar on Water Resources Systems Planning and Management (2002).

6) Vinithra R, Yeshodha L, "Rainfall-runoff modelling using SCS-CN method: a case study of Krishnagiri District, Tamilnadu”, Int. J Sci Res 5(3):2319-7064 (2016).

7) Amutha R, Porchelvan P, "Estimation of surface runoff in Malattar sub-watershed using SCS-CN method", J Soc Remote Sens 37 (2):291-304 (2009).

8) Ashok S.Sangle ,PravinL.Yannawar, "Morphometric analysis of watershed using GIS and RS - A Review", International journal of engineering research \& technology, ISSN:2278-0181, Vol.3 \& Issue 11, (2014).

9) USDA (1986) Urban hydrology for small Watersheds, TR-55, United States Department of Agriculture, 210-VI-TR-55, 2nd edn., June 1986.

10) USDA (1972) Soil Conservation Service, National Engineering Handbook, Hydrology Section 4, Chapters 4-10, Washington, D.C: USDA.

11) USDA-SCS (1974) Soil survey of Travis County, Texas. College Station, Tex.: Texas Agricultural Experiment Station, and Washington, D.C: USDA Soil Conservation Service. 